\title{
DIFFERENT-LIGAND AND DIFFERENT-METAL XYLARATOGERMANATES AS EFFECTORS OF PENICILLIUM RESTRICTUM IMV F-100139 $\alpha$-L-RHAMNOSIDASE AND $\alpha$-GALACTOSIDASE
}

\author{
O. V. GUDZENKO ${ }^{1 凶}$, N. V. BORZOVA ${ }^{1}$, L. D. VARBANETS ${ }^{1}$, \\ I. I. SEIFULLINA', O. A. CHEBANENKOㄹ , E. E. MARTSINKO ${ }^{2}$ \\ ${ }^{1}$ Zabolotny Institute of Microbiology and Virology, \\ National Academy of Sciences of Ukraine, Kyiv; \\ ${ }^{2}$ Odessa National University I.I. Mechnikov, Ukraine; \\ 凶e-mail:ov_gudzenko@bigmir.net
}

Received: 11 March 2021; Accepted: 22 September 2021

One of the ways to create new biologically active substances based on enzymes is to obtain highly efficient protein-complex structures. Studies in recent years have shown that the coordination compounds of "essential" germanium with biologically active hydroxycarboxylic and, in particular, with xylaric, acids are characterized by low toxicity and a wide range of pharmacological action. In addition, many of them have proven to be activators of various enzymes. In this regard, the aim of work was to study the effects of mixed ligand and heterometallic coordination compounds of germanium with xylaric acid on the catalytic and some physicochemical properties of Penicillium restrictum IMV F-100139 $\alpha$-galactosidase and $\alpha$-L-rhamnosidase. $\alpha$-Galactosidase activity was determined using $p$-nitrophenyl- $\alpha$-D-galactopyranoside as a substrate. The activity of $\alpha$-L-rhamnosidase was determined using the Davis method. As modifiers of enzyme activity differentligand and different-metalxylaratogermanates have been used. It was shown that the coordination compound (7) tris(bipyridine)nickel(II) $\mu$-dihydroxyxylaratogermanate(IV) ([Ni(bipy) $]_{2}\left[(\mathrm{OH})_{2} \mathrm{Ge}_{2}(\mu \text { - } \mathrm{HXylar})_{4} \mathrm{Ge}_{2}(\mu\right.$ $\left.\mathrm{OH})_{2}\right] \cdot 2 \mathrm{OH}_{2} \mathrm{O} \cdot 2 \mathrm{C}_{2} \mathrm{H}_{5} \mathrm{OH}$ ) exerted a significant effect on the catalytic properties of $\alpha$-L-rhamnosidase and $\alpha$-galactosidase from $P$. restrictum. The activation and thermal stabilization of $P$. restrictum $\alpha$ - $L$-rhamnosidase in the presence of (7) is based on the combination of all constituents of the effector molecule: cation [Ni(bipy) $\left.]_{3}\right]^{2+}$ and anion $\left[(\mathrm{OH})_{2} \mathrm{Ge}_{2}(\mu-\mathrm{HXylar})_{4} \mathrm{Ge}_{2}(\mu-\mathrm{OH})_{2}\right]^{4-}$ metal complex, as well as the location of aromatic amino acids in the enzyme molecule. Weak non-covalent bonds between P. restrictum $\alpha$-L-rhamnosidase molecules and compound (7) appear to create the conformation that is most favorable for the convergence of the active sites of the enzyme with the substrate.

Ke y wo rd s: Penicillium restrictum IMV F-100139, $\alpha$-galactosidase, $\alpha$-L-rhamnosidase, xylaratogermanates of different ligands and different metals.

A t present, there has been an increased interest in the use of highly effective enzyme preparations with useful properties for their use in the food, pharmaceutical, chemical industries, as well as medicine. At the same time, special attention of researchers is attracted by glycosidases - enzymes of the class of hydrolases (O-glycoside hydrolases), which are capable of catalyzing the hydrolysis of O-glycosidic bonds in glycosides, oligo-, polysaccharides, glycolipids and other glycoconjugates. Some of these enzymes are $\alpha$-galactosidase and $\alpha$-L-rhamnosidase.

$\alpha$-Galactosidase (EC 3.2.1.22) is a glycosyl hydrolase, capable of cleaving, as a rule, while maintaining their optical configuration, terminal non-reducing residues of $\alpha$-D-galactose from $\alpha$-Dgalactosides, including galactooligosaccharides, galactomannans and galactolipids. Their simplest natural substrates are melibiose disaccharide and raffinose trisaccharide. In some cases, $\alpha$-galactosidases 
have been found to have transgalactosidase activity. Wide opportunities for the use of $\alpha$-galactosidases open up in such areas as the food industry, in particular for increasing the yield of sugar from molasses [1, 2], as feed additives to increase the nutritional value of soy products due to the hydrolysis of galactooligosaccharides of raffinose and stachyose, in the production of oligosaccharides of probiotic action, as well as dietary food for children and the elderly [2]. Enzyme preparations are also promising in medicine: for enzyme therapy of some hereditary human diseases, in xenotransplantation, for biotransformation of human erythrocytes of group B (III) into donor erythrocytes of O-type [3].

$\alpha$-L-Rhamnosidase (EC 3.2.1.40) hydrolytically cleaves off terminal unreduced residues of L-rhamnose, which are present in both synthetic and natural glycosides, oligo-, polysaccharides, glycolipids and various glycoconjugates, derivatives of flavonoids: rutin, neohesperidin, hesperidin, naringin, quercetrin; saponinss: ginsenosides; terpene glucosides; asiaticosides. Only in quercetrin, L-rhamnose is directly linked to the aglycon moiety, while all other substrates are glycosides, in which L-rhamnose is linked to the $\beta$-D-glucopyranosyl residue via various types of glycosidic bonds: $\alpha-1,2, \alpha-1,4$ and $\alpha-1,6$. $\alpha$-L-Rhamnosidases are used to create, based on glycosides of plant origin, such as rutin, quercetrin, hesperidin, drugs for the treatment of cardiovascular diseases, compounds with antiviral and immunotropic effects [4]. By hydrolyzing terpene glycosides, the enzyme helps to release aromatic compounds that enhance the aroma of grape juices and wines; therefore it is used in the food industry.

One of the ways to obtain new biologically active substances based on enzymes is the use of metal complex catalysts, in particular, various coordination compounds. Recent studies have established that the coordination compounds of "essential" germanium with biologically active hydroxycarboxylic acids, widely used in the food industry and medicine, in particular with xylaric acids, are characterized by low toxicity and a wide spectrum of pharmacological action: antioxidant, antiviral, antihypoxic, hepatoprotective, cerebroprotective, neuroprotective [5]. Along with this, many of them have shown themselves to be effectors of various enzymes [6-9]. This indicates that the study of various types of xylaratogermanates as modifiers of enzymes is promising. We were unable to find any works by foreign authors on the effect of such structures on the activity of enzymes.
Previously, as a result of screening cultures of microorganisms isolated from the soils of the Chernobyl exclusion zone the strain Penicillium restrictum IMV F-100139 was selected, which is characterized by a high level of $\alpha$-galactosidase and $\alpha$-Lrhamnosidase activity [10].

In this regard, the aim of work was to study the peculiarities of the effect of mixed-ligand and heterometallic coordination compounds of germanium with xylaric acid on the catalytic and some physicochemical properties of $\alpha$-galactosidase and $\alpha$-L-rhamnosidase of Penicillium restrictum IMV F-100139.

\section{Materials and Methods}

The objects of research were $\alpha$-galactosidase and $\alpha$-L-rhamnosidase $P$. restrictum IMV F-100139 from the collection of live cultures of the D.K. Zabolotny IMV NAS of Ukraine. Fungal strain was grown in medium containing (g/l): $\mathrm{KH}_{2} \mathrm{PO}_{4}-10.0$; $\mathrm{MgSO}_{4} \times 7 \mathrm{H}_{2} \mathrm{O}-3.0 ;\left(\mathrm{NH}_{4}\right)_{2} \mathrm{SO}_{4}-2.0 ; \mathrm{CaCl}_{2}-1.0$; yeast autolysate -0.15 ; soy flour - 10.0 ; rhamnose 5 . The value of the liquid medium $\mathrm{pH}$ was adjusted to 5.0 , and the culture was incubated at $25^{\circ} \mathrm{C}$ in an orbital shaker at $220 \mathrm{rpm}$ for 6 days.

A crude preparation of enzymes was obtained from the supernatant of culture liquids of $P$. restrictum by precipitation with ammonium sulfate to $90 \%$ saturation. After centrifugation of mixture at $5000 \mathrm{~g}, 30 \mathrm{~min}, 4^{\circ} \mathrm{C}$ precipitate was obtained, that then dialyzed against $10 \mathrm{mM}$ phosphate buffer (pH 6.0). The dialyzed enzyme solution was applied to a Toyopearl HW-60 (Toyo Soda, Japan) column $(2.5 \times 90 \mathrm{~cm})$, equilibrated with $0.01 \mathrm{M}$ phosphate buffer, $\mathrm{pH}$ 6.0. Fractions exhibiting $\alpha$-galactosidase and $\alpha$-L-rhamnosidase activity were collected and concentrated by evaporating under vacuum. The resultant preparation was applied to Fractogel DEAE-650-s (Merck, Germany) column $(3 \times 35 \mathrm{~cm})$, equilibrated with $0.01 \mathrm{M}$ Tris-HCl buffer, $\mathrm{pH}$ 7.5. Elution was performed by the $\mathrm{NaCl}$ linear gradient (0-1 M, of $200 \mathrm{ml}$ each) at $24 \mathrm{ml} / \mathrm{h}$ rates. Collected fractions were screened for protein content $\left(\mathrm{A}_{280}\right)$ and $\alpha$-galactosidase and $\alpha$-L-rhamnosidase activities. The $\alpha$-L-rhamnosidase and $\alpha$-galactosidase eluted in two separatelic peaks. The fractions with $\alpha$-galactosidase activity and $\alpha$-L-rhamnosidase activity were combined separately and dialyzed against $0.1 \mathrm{M}$ PCB, pH 5.2, and the dialysates were used as the purified $\alpha$-galactosidase and $\alpha$-L-rhamnosidase throughout this study. Specific activities of the 
$\alpha$-galactosidase and $\alpha$-L-rhamnosidase were 6.5 and $1.2 \mathrm{U} / \mathrm{mg}$ of protein respectively.

$\alpha$-Galactosidase activity was determined using as a substrate p-nitrophenyl- $\alpha$-D-galactopyranoside (Sigma, USA) [11]. To determine activity $0.1 \mathrm{ml}$ of the enzyme solution was mixed with $0.2 \mathrm{ml} 0.1 \mathrm{M}$ phosphate-citrate buffer (PCB) $\mathrm{pH} 5.2$ and $0.1 \mathrm{ml}$ $0.01 \mathrm{M}$ substrate solution in PCB. The reaction mixture was incubated for $10 \mathrm{~min}$ at $37^{\circ} \mathrm{C}$. The reaction was stopped by adding $2 \mathrm{ml}$ of $1 \mathrm{M}$ sodium bicarbonate. The amount of released nitrophenol as a result of hydrolysis was determined colorimetrically by the absorption at $400 \mathrm{~nm}$. One unit of enzyme activity was defined as the amount of enzyme that releases $1 \mu \mathrm{mol}$ of p-nitrophenol per min at $37^{\circ} \mathrm{C}$ in $0.1 \mathrm{M}$ PCB, pH 5.2.

The activity of $\alpha$-L-rhamnosidase was determined using Davis method [12] with minor modification. The assay mixture contained $0.2 \mathrm{ml}$ of $0.1 \%$ naringin (Sigma, USA) solution in 0.1 M PCB $\mathrm{pH} 5.2$ and $0.2 \mathrm{ml}$ enzyme solution. After incubation at $37^{\circ} \mathrm{C}$ for $30 \mathrm{~min}$, the reaction was stopped by addition of $5 \mathrm{ml}$ diethylene glycol (90\%) and $0.1 \mathrm{ml}$ of $4 \mathrm{~N} \mathrm{NaOH}$. The residual naringin was measured at $420 \mathrm{~nm}$. One unit of $\alpha$-L-rhamnosidase activity was defined as the amount of enzyme that releases $1 \mu \mathrm{mol}$ of naringin per min in the solution.

As modifiers of enzyme activity, we used

12 coordination compounds of germanium:

(1) protonated phenanthroline $\mu$-dihydroxyxylaratogermanate(IV) $\left((\mathrm{HPhen})_{4}\left[(\mathrm{OH})_{2} \mathrm{Ge}_{2}(\mu-\right.\right.$ HXylar) $\left.\left.{ }_{4} \mathrm{Ge}_{2}(\mu-\mathrm{OH})_{2}\right] \cdot 13 \mathrm{H}_{2} \mathrm{O}\right)$,

(2) bis(phenanthroline)chlorocopper(II) $\mu$-dihydroxyxylaratogermanate(IV) ([CuCl(Phen $\left.)_{2}\right]_{4}\left[(\mathrm{OH})_{2} \mathrm{Ge}_{2}(\mu-\mathrm{HXylar})_{4} \mathrm{Ge}_{2}(\mu-\right.$ $\left.\mathrm{OH})_{2}\right] \cdot 8 \mathrm{H}_{2} \mathrm{O}$ ),

(3) tris(phenanthroline)copper(II) $\mu$-dihydroxyxylaratogermanate (IV) $\left(\left[\mathrm{Cu}(\mathrm{Phen})_{3}\right]_{2}\left[(\mathrm{OH})_{2} \mathrm{Ge}_{2}(\mu-\right.\right.$ HXylar $\left.\left.)_{4} \mathrm{Ge}_{2}(\mu-\mathrm{OH})_{2}\right] \cdot 8 \mathrm{H}_{2} \mathrm{O}\right)$,

(4) tris(bipyridine)copper(II) $\mu$-dihydroxyxylaratogermanate $(\mathrm{IV})\left(\left[\mathrm{Cu}(\text { bipy })_{3}\right]_{2}\left[(\mathrm{OH})_{2} \mathrm{Ge}_{2}(\mu-\right.\right.$ HXylar) $\left.\left.4 \mathrm{Ge}_{2}(\mu-\mathrm{OH})_{2}\right] \cdot 14 \mathrm{H}_{2} \mathrm{O} \cdot 2 \mathrm{C}_{2} \mathrm{H} 5 \mathrm{OH}\right)$,

(5) tris(bipyridine)zinc $\mu$-dihydroxyxylaratogermanate $(\mathrm{IV}) \quad\left(\left[\mathrm{Zn}(\text { bipy })_{2}\right]_{2}\left[(\mathrm{OH})_{2} \mathrm{Ge}_{2}(\mu-\right.\right.$ HXylar) $\left.\left.{ }_{4} \mathrm{Ge}_{2}(\mu-\mathrm{OH})_{2}\right] \cdot 18 \mathrm{H}_{2} \mathrm{O} \cdot 2 \mathrm{C}_{2} \mathrm{H}_{5} \mathrm{OH}\right)$,

(6) tris(phenanthroline)nickel(II) $\mu$-dihydroxyxylaratogermanate $(\mathrm{IV})\left(\left[\mathrm{Ni}(\mathrm{Phen})_{3}\right]_{2}\left[(\mathrm{OH})_{2} \mathrm{Ge}_{2}(\mu-\right.\right.$ HXylar $\left.\left.)_{4} \mathrm{Ge}_{2}(\mu-\mathrm{OH})_{2}\right] \cdot 8 \mathrm{H}_{2} \mathrm{O}\right)$,

(7) tris(bipyridine)nickel(II) $\mu$-dihydroxyxylaratogermanate(IV) ([Ni(bipy) $]_{3}\left[(\mathrm{OH})_{2} \mathrm{Ge}_{2}(\mu-\right.$ HXylar) $\left.\left.{ }_{4} \mathrm{Ge}_{2}(\mu-\mathrm{OH})_{2}\right] \cdot 20 \mathrm{H}_{2} \mathrm{O} \cdot 2 \mathrm{C}_{2} \mathrm{H}_{5} \mathrm{OH}\right)$,
(8) tris(bipyridine)iron(II) $\mu$-dihydroxyxylaratogermanate(IV) ([Fe(bipy) $]_{2}\left[(\mathrm{OH})_{2} \mathrm{Ge}_{2}(\mu-\right.$ HXylar) $\left.\left.{ }_{4} \mathrm{Ge}_{2}(\mu-\mathrm{OH})_{2}\right] \cdot 12 \mathrm{H}_{2} \mathrm{O} \cdot 2 \mathrm{C}_{2} \mathrm{H}_{5} \mathrm{OH}\right)$,

(9) tris(phenanthroline)iron(II) $\mu$-dihydroxyxylaratogermanate(IV) $\left(\left[\mathrm{Fe}(\mathrm{Phen})_{3}\right]_{2}\left[(\mathrm{OH})_{2} \mathrm{Ge}_{2}(\mu-\right.\right.$ HXylar) $\left.\left.{ }_{4} \mathrm{Ge}_{2}(\mu-\mathrm{OH})_{2}\right] \cdot 6 \mathrm{H}_{2} \mathrm{O} \cdot \mathrm{C}_{2} \mathrm{H}_{5} \mathrm{OH}\right)$,

(10) copper(II) $\mu$-dihydroxyxylaratogermanate(IV) - cuprate(II) $\left(\left[\mathrm{Cu}\left(\mathrm{H}_{2} \mathrm{O}\right)_{6}\right]\left[\mathrm{Ge}\left(\mu_{3}-\right.\right.\right.$ Xylar) $\left.\left.{ }_{2}\left\{\mathrm{Cu}\left(\mathrm{H}_{2} \mathrm{O}\right)_{2}\right\}_{2}\right] \cdot 2 \mathrm{H}_{2} \mathrm{O}\right)$,

(11) nickel(II) $\mu$-dihydroxyxylaratogermanate(IV) - nickelate(II) $\left(\left[\mathrm{Ni}\left(\mathrm{H}_{2} \mathrm{O}\right)_{6}\right]\left[\mathrm{Ge}\left(\mu_{3}-\right.\right.\right.$ Xylar) $\left.\left.{ }_{2}\left\{\mathrm{Ni}\left(\mathrm{H}_{2} \mathrm{O}\right)_{2}\right\}_{2}\right] \cdot 2 \mathrm{H}_{2} \mathrm{O}\right)$,

(12) zinc $\mu$-dihydroxy xylaratogermanate(IV)-zincate $\left(\left[\mathrm{Zn}\left(\mathrm{H}_{2} \mathrm{O}\right)_{6}\right]\left[\mathrm{Ge}\left(\mu_{3} \text {-Xylar }\right)_{2}\left[\mathrm{Zn}\left(\mathrm{H}_{2} \mathrm{O}\right)_{2}\right\}_{2}\right] \cdot 2 \mathrm{H}_{2} \mathrm{O}\right)$.

The composition and structure of these compounds was established using a combination of physical and chemical research methods: elemental analysis, thermogravimetry, IR spectroscopy and Xray structural analysis $[13,14]$. Structures of seven compounds are deposited in the Cambridge Crystallographic Database: 1883675 (1), 1999455 (2), 1999453 (3), 1883677 (6), 1569267 (7), 1569266 (8), 1883676 (9).

All complexes are cation-anionic compounds. In 1-9, the same homometallic tetrameric $\mu$-dihydroxyxylaratogermanate anion $\left[(\mathrm{OH})_{2} \mathrm{Ge}_{2}\right.$ ( $\mu$-HXylar) $\left.{ }_{4} \mathrm{Ge}_{2}(\mu-\mathrm{OH})_{2}\right]$ is realized, and in 10-12 the heterometallic three-nuclear anion [Ge $\left(\mu_{3} \text {-Xylar }\right)_{2}$ $\left.\left\{\mathrm{M}\left(\mathrm{H}_{2} \mathrm{O}\right)_{2}\right\}_{2}\right]^{2}$. The anion charge is compensated for by the following cations: protonated 1,10-phenanthroline (HPhen ${ }^{+}$) molecules (1), 3d-metal complex cations (2-9), and 3d-metal hexaaquacations (1012). Schemes of compounds structures are shown in Fig. 1.

When studying the effect of various compounds on the activity of enzymes, concentrations of 0.1 and $0.01 \%$ were used, exposure times were 0.5 and $24 \mathrm{~h}$. The test compounds were dissolved in $0.1 \%$ DMSO.

The optimum temperature of native and modified enzymes was determined by incubating the assay mixture for $30 \mathrm{~min}$ at temperature ranging from 4 to $80^{\circ} \mathrm{C}$ (pH 5.0). Thermal stability was measured by preincubation of the enzymes at the $\mathrm{pH} 5.0$ at different temperatures $\left(65,70\right.$ and $\left.75^{\circ} \mathrm{C}\right)$ with the exposition time of 3.5 hours; the aliquots in $0.1 \mathrm{ml}$ were collected in definite intervals (10-30 min) for measurement of residual activity.

UV-spectra of absorption of native and chemical modified preparations of the enzymes were studied by spectrophotometer-fluorimeter DeNovix DS-11 in the range of 220-340 nm, concentration of the enzyme preparation $1.0 \mathrm{mg}$ of protein $/ \mathrm{ml}$. 


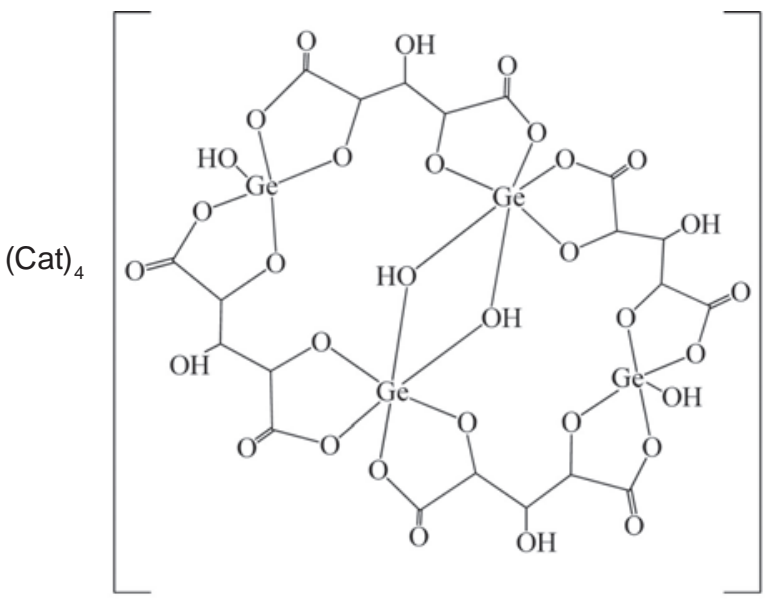<smiles></smiles>

(1)

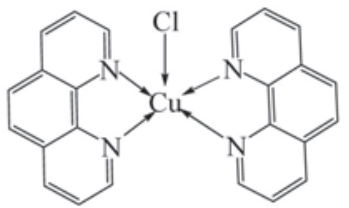

(2)

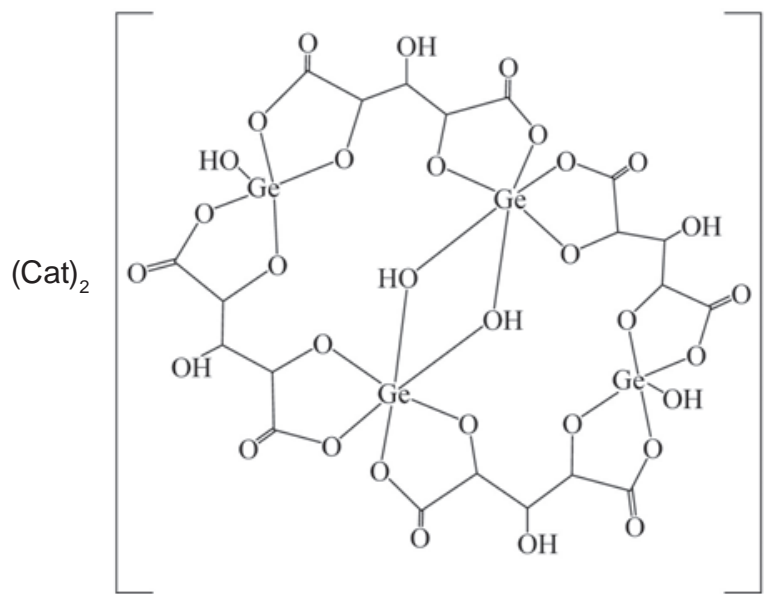

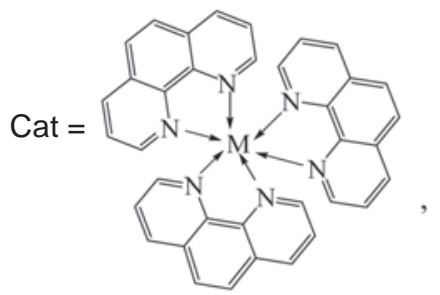

$\mathrm{M}=\mathrm{Cu}(\mathbf{3}), \mathrm{Ni}(\mathbf{6}), \mathrm{Fe}(\mathbf{9})$

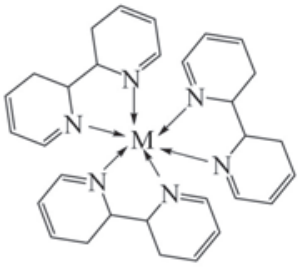

$\mathrm{M}=\mathrm{Cu}(4), \mathrm{Zn}(5)$, $\mathrm{Ni}(7), \mathrm{Fe}(8)$

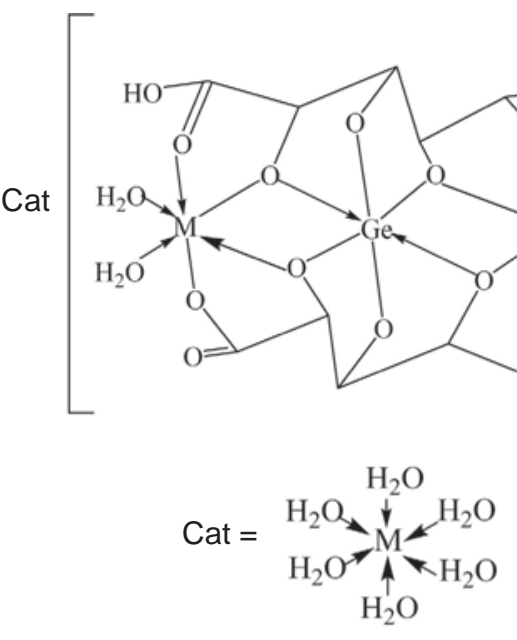

$\mathrm{M}=\mathrm{Cu}$ (10), Ni (11), Zn (12)

Fig. 1. Schemes of structures 1-12

All experiments were carried out in seven replicates. The analysis of the results obtained was carried out by statistical processing using the Student's $t$-test. In the work, the mean values and standard errors $(M \pm m)$ were calculated. Values at $P<0.05$ were considered significant. The results, which are shown graphically, were processed using Microsoft Excel 2007.

\section{Results and Discussion}

As a result of gel permeation chromatography and ion exchange chromatography of $P$. restrictum culture liquid, two enzymes with $\alpha$-galactosidase and $\alpha$-L-rhamnosidase activities were isolated. The specific $\alpha$-L-rhamnosidase and $\alpha$-galactosidase activity of preparations were 1.20 and $6.5 \mathrm{U} / \mathrm{mg}$ respectively. 
As modifiers of enzyme activity, 12 above mentioned related compounds were used. They are fine-crystalline precipitates of different colors, stable in air, and do not hydrolyze. In solutions, they dissociate with the formation of the corresponding cations and anions (Fig. 1).

Analysis of the data obtained (Fig. 2) showed that germanium compounds had different effects on the activity of the studied enzyme preparations. So, most of the studied complexes, regardless of the concentration used and the incubation time, had practically no effect on the $\alpha$-galactosidase activity of $P$. restrictum IMV F-100139. A slight decrease in enzyme activity (3-17\%) was observed when using complexes (3), (7), (8) at concentrations of $0.01 \%$ and $0.1 \%$ (exposure time $1 \mathrm{~h}$ and $24 \mathrm{~h}$ ), as well as compound (4) (inhibition of 7\%) at a concentration of $0.1 \%$ with different duration of action.

However, in general, the noted impact did not go beyond the statistical error. We have previously studied the effect of various complex compounds of germanium, zinc, cobalt, and nickel on $\alpha$-galactosidases and proteases from other producers $[6,8]$. And it should be noted that in almost all cases we did not observe changes in the activity of $\alpha$-galactosidases, although we observed significant activation or inhibition of proteolytic enzymes $[6,8]$. Perhaps this is due to the size of the molecule of the studied enzymes: the used $\alpha$-galactosidases had a molecular weight of about $400 \mathrm{kDa}$, while proteases - up to $40 \mathrm{kDa}[15,16]$.

A completely different picture was observed when studying the effect of the studied coordination compounds on the $\alpha$-L-rhamnosidase activity of $P$. restrictum IMV F-100139 (Fig. 3). Compared to the effect on $P$. restrictum $\alpha$-galactosidase, where only a slight inhibitory effect of some substances was noted, the $\alpha$-L-rhamnosidase activity of $P$. restrictum IMV F-100139 slightly decreased (by 3\%) only under the action of compound (12) at a concentration of $0.01 \%$. With an increase in concentration to $0.1 \%$, most of the tested compounds either did not affect the activity of the studied $\alpha$-L-rhamnosidase, or activated it from 10 to $800 \%$. The greatest activating effect is inherent in the substance (7), which increased the activity of the enzyme by 8 times.

In general, we noted a more varied effect of the investigated substances at a concentration of $0.1 \%$, at which almost all compounds activated $P$. restrictum $\alpha$-L-rhamnosidase by $10-800 \%$. With an increase in the exposure hour, activation of $\alpha$-L-rhamnosidase by compounds (2) - (10) was noted.
Based on the above, it can be noted that compound (7) has the greatest modifying effect among the studied substances. To clarify the nature of this action, we studied some of the physical properties of native and modified preparations of $\alpha$-galactosidase and $\alpha$-L-rhamnosidase.

It is known that in the presence of a metal complex, new intramolecular and intermolecular bonds can form, which in turn leads to an increase in the hydrophobicity or hydrophilicity of the enzyme molecule, an increase in its rigidity, etc. Such changes, in turn, lead to a change in the resistance of the molecule to denaturation, including thermal. It was shown that the presence of compound (7) did not affect the thermooptimum of the action of both enzymes (Fig. 4, A, B). It was shown (Fig. 4, A) that the thermooptimal action of the native and modified $\alpha$-L-rhamnosidase was the same and amounted to $65^{\circ} \mathrm{C}$. The thermooptimum of $\alpha$-galactosidase in the presence of compound (7) also did not shift relative to the optimum values of the native enzyme $\left(60^{\circ} \mathrm{C}\right)$, however, an increase in the rate of enzyme inactivation was noted at temperatures above the optimum (Fig. 4, B).

Conformational changes that led to an increase in the catalytic activity of the enzyme can also affect the change in the thermal stability of the protein. In this regard, we studied the thermal inactivation of $P$. restrictum glycosidases in the temperature range $65-75^{\circ} \mathrm{C}$. High thermal stability was shown for both native $P$. restrictum $\alpha$-L-rhamnosidase and modified (Fig. 5). Thus, incubation of $\alpha$-L-rhamnosidase at $65^{\circ} \mathrm{C}$ for $1 \mathrm{~h}$ retained $50 \%$ of the enzyme activity, and in the presence of compound (7) in the reaction medium, $90 \%$. After $2.5 \mathrm{~h}$ of incubation at $65^{\circ} \mathrm{C}$, only $20 \%$ of the activity of the native enzyme preparation was retained, while in the presence of substance (7) 50\%. A similar picture was observed at higher temperatures. Thus, at 70 and $75^{\circ} \mathrm{C}$, the enzyme preparation in the presence of compound (7) was more stable than the native enzyme.

Thus, it was shown that compound (7) increases the thermal stability of $P$. restrictum $\alpha-\mathrm{L}-$ rhamnosidase (Fig. 5). The thermal stability of the native and modified $\alpha$-galactosidase of $P$. restrictum did not differ under the experimental conditions.

The production and effectiveness of new biologically active substances, including those based on enzymes and coordination compounds of metals, largely depend on information on the interaction between receptors and ligands, aromatic amino acids 

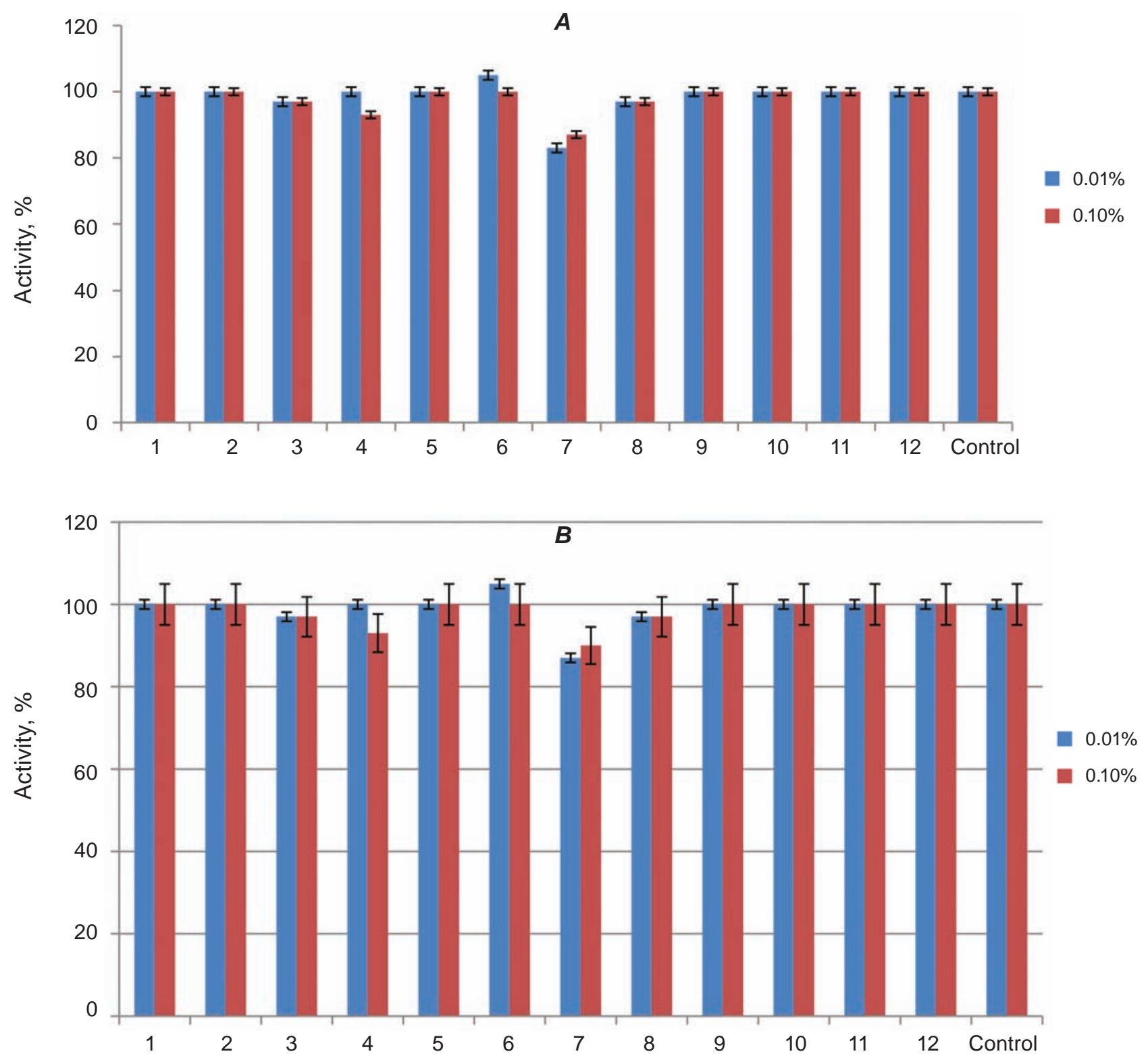

Fig. 2. Influence of germanium compounds on the activity of P. restrictum $\alpha$-galactosidase. A-exposure time $1 \mathrm{~h}, \boldsymbol{B}$-exposure time $24 \mathrm{~h}$

and organic (protonated amino acids) or inorganic (protons and metals) cation [17]. In many cases, the formation of active protein-complex structures depends on a delicate balance of several types of weak molecular interactions.

We have studied the UV absorption spectra of native $\alpha$-L-rhamnosidase and the enzyme in the presence of compound (7), which may give some answers regarding the nature of their interaction. In the presence of compound (7), hyperchroism of the $\alpha$-L-rhamnosidase protein was observed in the ranges of 220, 245, and 290-300 nm (Fig. 6). No such effect was observed for $\alpha$-galactosidase. UV absorp- tion of proteins in the range from 180 to $230 \mathrm{~nm}$ is almost completely associated with $\pi \rightarrow \pi^{*}$ transitions in peptide bonds. The absorption in the range of 230-300 $\mathrm{nm}$ is dominated by aromatic side chains of tryptophan (Trp), tyrosine (Tyr), and phenylalanine (Phe) residues. It was noted that the absorption rate increases with increasing concentration of compound (7).

It is known that the cationic and aromatic side chains of amino acid residues interact to stabilize the secondary, tertiary and quaternary structure of the protein. Stabilization is partly due to electrostatic attraction between the cation and regions of 

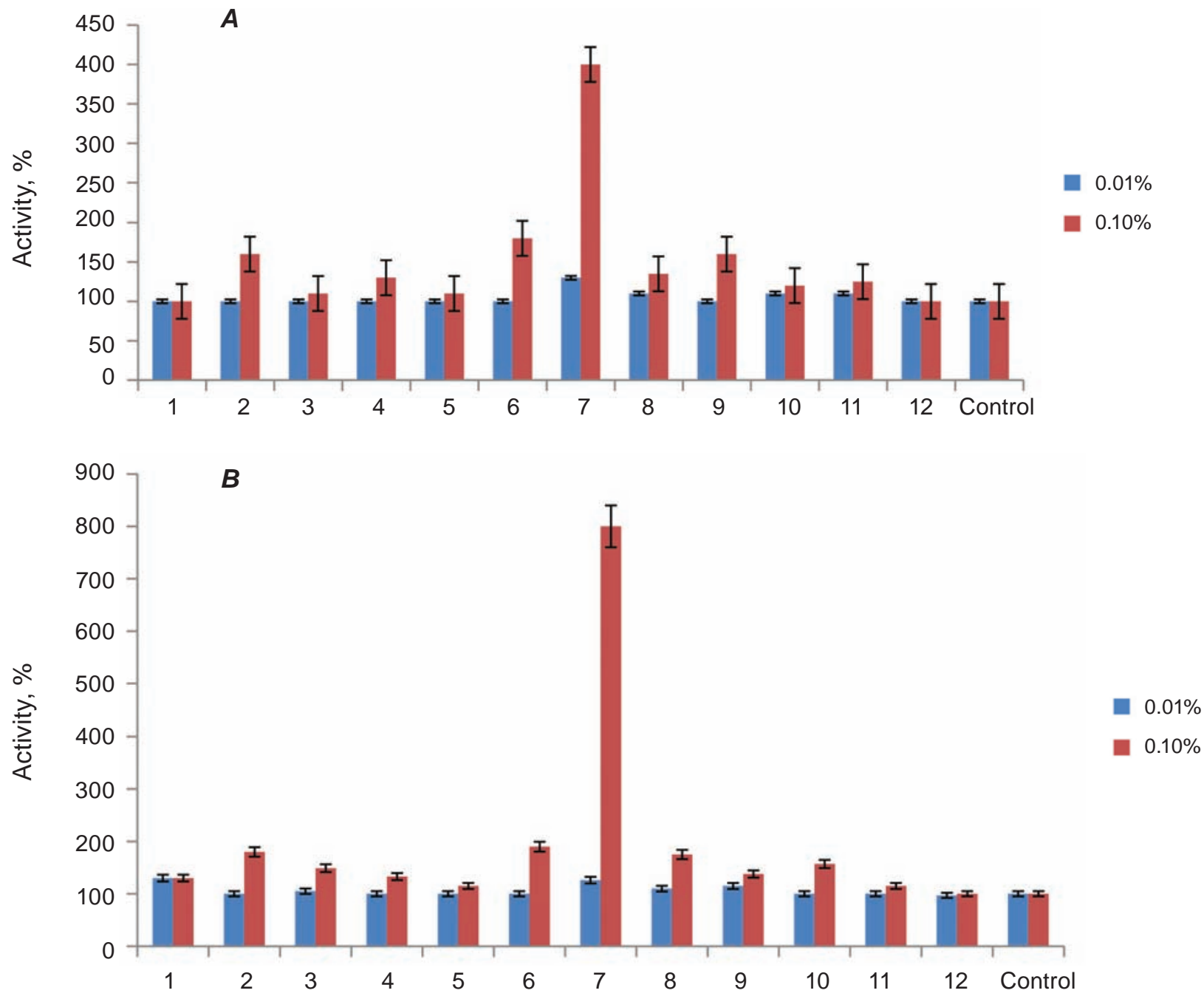

Fig. 3. Influence of germanium compounds on the activity of P. restrictum $\alpha$-L-rhamnosidase. $\boldsymbol{A}$ - exposure time $1 \mathrm{~h}, \boldsymbol{B}$-exposure time $24 \mathrm{~h}$

high electron density in the $\pi$-orbitals of the aromatic group, which gave the name to this type of interaction - cation- $\pi$ [18]. In the presence of chemical compounds, a redistribution of these weak intramolecular interactions can occur, which is reflected in a change in the conformation of the protein and/or the topology of the active center, and as a result, we observe a change in the catalytic properties of the enzyme.

Data on the high thermal stability of $P$. restrictum $\alpha$-L-rhamnosidase are extremely interesting. Elucidation of the factors responsible for the manifestation of extreme thermal stability of proteins is very important both for understanding the mechanism of protein stability and for the development of stable enzymes. We observed a fairly high thermal stability of the enzymes of the mesophilic fungus
P. restrictum in the temperature range of $65-75^{\circ} \mathrm{C}$. The data obtained on the basis of UV spectra of $P$. restrictum $\alpha$-L-rhamnosidase indicate a significant contribution of aromatic amino acids to both, possibly, the topology of the active center, and the thermal stabilization of the enzyme in the presence of compound (7) due to weak cation- $\pi$ interactions. In recent years, studies have appeared showing the importance of cation- $\pi$ interactions both for the manifestation of the catalytic properties of enzymes and for their thermal stabilization [19]. There is evidence that, in mesophiles, Phe residues play a key role in the cation- $\pi$ interaction, while for thermophiles Tyr has a greater effect [20].

The peculiarities of the conformation of the $P$. restrictum $\alpha$-galactosidase molecule seem to allow it to retain its native structure in the presence 

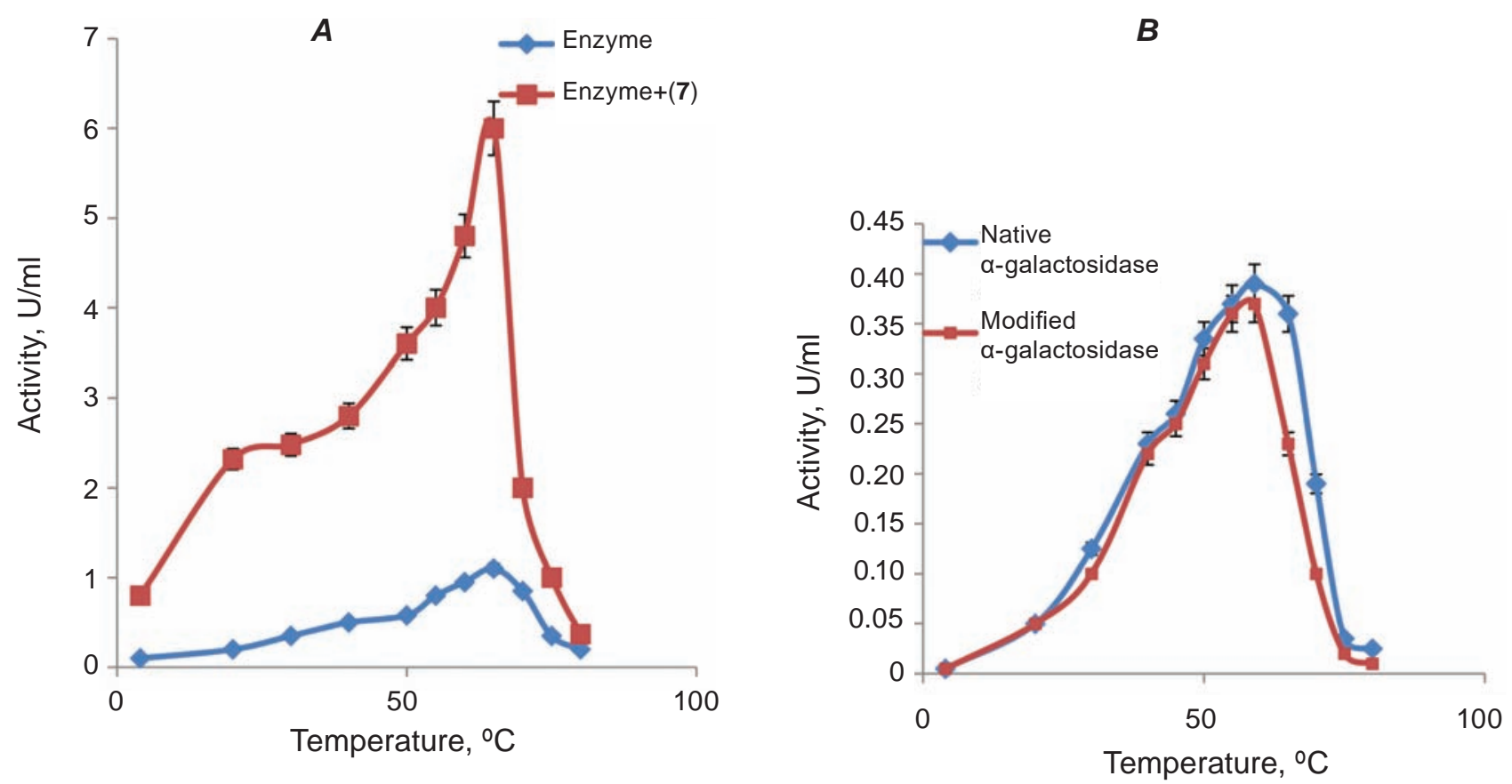

Fig. 4. The optimum temperature of P. restrictum enzymes(pH 5.0): $\boldsymbol{A}-\alpha$-L-rhamnosidase, $\boldsymbol{B}-\alpha$-galactosidase

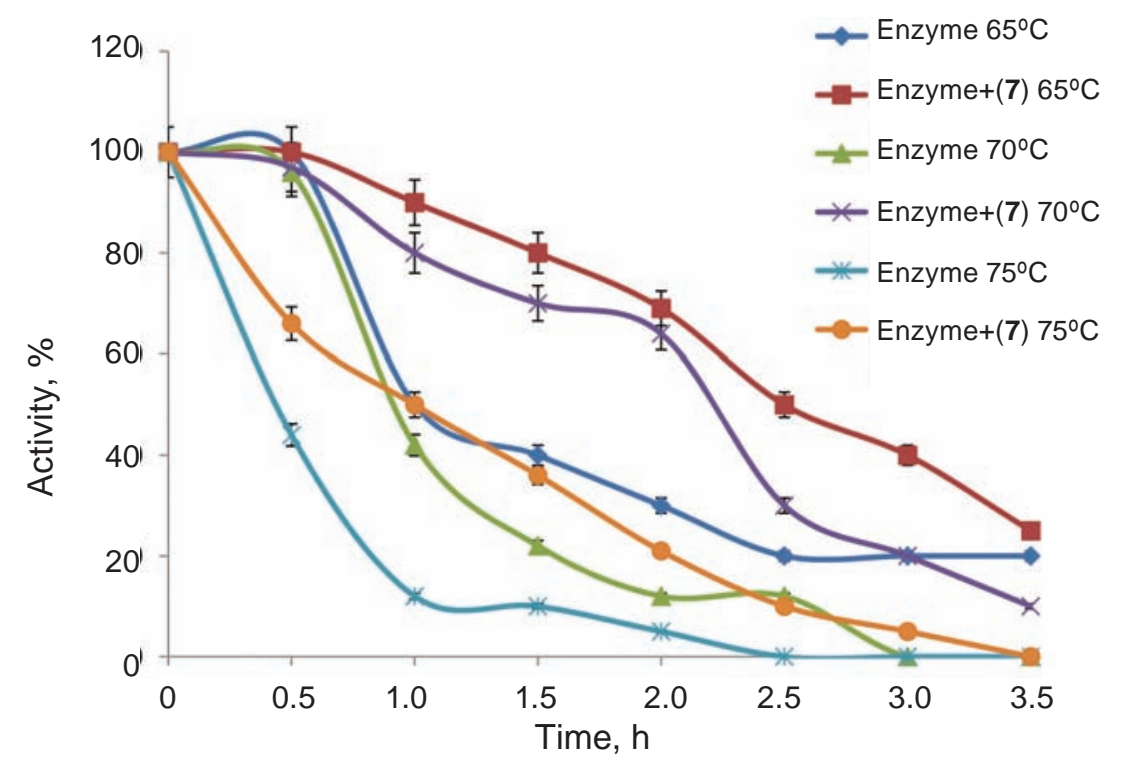

Fig. 5. Thermal stability of P. restrictum $\alpha$-L-rhamnosidase

of compound (7). Or, these changes do not affect the catalytically important parts of the molecule.

Thus, as a result of the research, the effect of 12 coordination metal compounds on the activity of enzymes was studied. It was shown that a coordination compound (7) exerted a significant effect on the catalytic properties of $\alpha$-L-rhamnosidase and $\alpha$-galactosidase from $P$. restrictum. The activation and thermal stabilization of $P$. restrictum
$\alpha$-L-rhamnosidase in the presence of (7) is based on the combination of all constituents of the complex molecule: the $\left[\mathrm{Ni} \text { (bipy) }{ }_{3}\right]^{2+}$ complex cation and the anion $\left[(\mathrm{OH})_{2} \mathrm{Ge}_{2}(\mu-\mathrm{HXylar})_{4} \mathrm{Ge}_{2}(\mu-\mathrm{OH})_{2}\right]^{4-}$, as well as the features of the conformation of the enzyme molecule, first of all, the availability of aromatic amino acids. The interaction of $P$. restrictum $\alpha$-Lrhamnosidase and compound (7), apparently, creates a conformation that is most favorable for the con- 


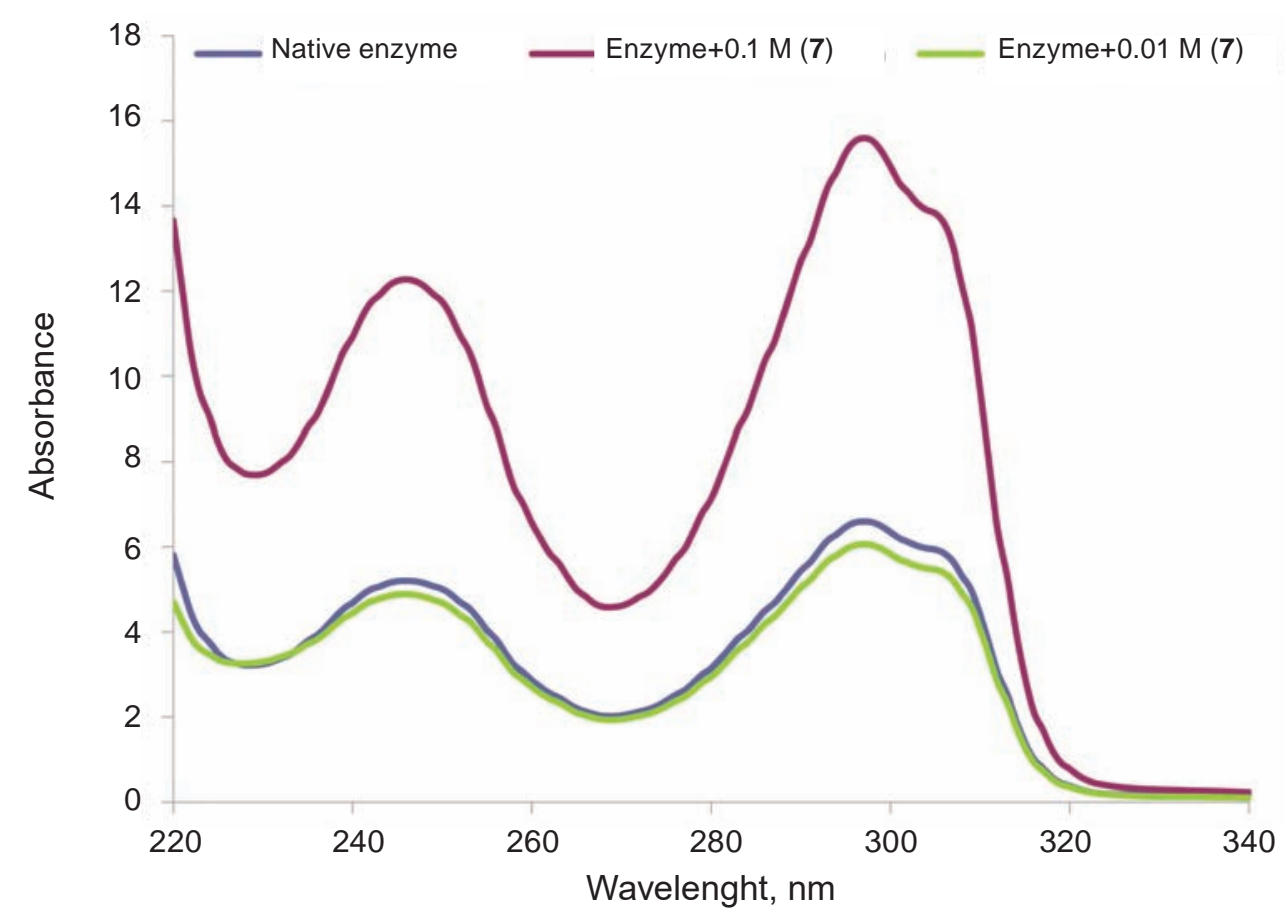

Fig. 6. UV absorption spectra of native P. restrictum $\alpha$-L-rhamnosidase, as well as enzyme under the action of compound (7)

vergence of the active sites of the enzyme with the substrate.

Conflict of interest. Authors have completed the Unified Conflicts of Interest form at http://ukrbiochemjournal.org/wp-content/uploads/2018/12/ coi_disclosure.pdf and declare no conflict of interest.
Funding. The research is done in the framework of the budget project No 0119U002195 "Direct synthesis strategy of different coordination compounds - medical substances with the wide range of pharmacological activity". 
РІЗНОЛІГАНДНІ ТА

РІЗНОМЕТАЛЬНІ

КСИЛАРАТОГЕРМАНАТИ ЯК

ЕФЕКТОРИ $\alpha$-L-PАМНОЗИДАЗИ

ТА $\alpha$-ГАЛАКТОЗИДАЗИ Penicillium restrictum IMV F-100139

О. В. Гудзенко ${ }^{1 \bowtie}$, Н. В. Борзова ${ }^{1}$,

Л. Д. Варбанеиь ${ }^{1}$, І. Й. Сейфулліна ${ }^{2}$,

О. А. Чебаненко 2 О. Е. Мариинко

${ }^{1}$ Інститут мікробіології і вірусології

ім. Д. К. Заболотного НАН України, Київ;

${ }^{2}$ Одеський національний університет

ім. I. І. Мечникова, Україна;

凶e-mail: ov_gudzenko@bigmir.net

Одним із способів створення нових біологічно активних речовин на основі ензимів $\epsilon$ одержання високоефективних протеїново-комплексних структур. Дослідженнями в останні роки встановлено, що координаційні сполуки «замінного» германію $з$ біологічно активними гідроксикарбоновими i, зокрема, ксилариновими кислотами характеризуються низькою токсичністю та широким спектром фармакологічної дії. Крім того, багато з них є активаторами різних ензимів. У зв'язку з цим метою роботи було з'ясувати особливості впливу змішаних лігандних та гетерометалічних координаційних сполук германію із ксиларовою кислотою на каталітичні та деякі фізико-хімічні властивості $\alpha$-галактозидази та $\alpha$-L-рамнозидази Penicillium restrictum IMB F-100139. Активність $\alpha$-галактозидази визначали, використовуючи як субстрат $n$-нітрофеніл- $\alpha$-D-галактопіранозид, a активність $\alpha$-L-рамнозидази - за допомогою методу Девіса. Модифікаторами ензиматичної активності були ксиларатогерманати різних лігандів та різних металів. Показано, що координаційна сполука (7) [трис (біпіридин) нікель (II) $\mu$-дигідроксиксиларатогерманат (IV) ([Ni(bipy) $\left.]_{3}\right]_{2}\left[(\mathrm{OH})_{2} \mathrm{Ge}_{2}(\mu-\mathrm{HXylar})_{4} \mathrm{Ge}_{2}(\mu-\right.$ $\left.\left.\mathrm{OH})_{2}\right] \cdot 20 \mathrm{H}_{2} \mathrm{O} \cdot 2 \mathrm{C}_{2} \mathrm{H}_{5} \mathrm{OH}\right)$ мала значний вплив на каталітичні властивості $\alpha$-L-рамнозидази та $\alpha$-галактозидази з P. restrictum. Активація та термічна стабілізація $\alpha$-L-рамнозидази $P$. restrictum у присутності (7) базується на взаємодії всіх складових молекули ефектора: катіона $\left[\mathrm{Ni}(\text { bipy })_{3}\right]^{2+}$ та аніона $\left[(\mathrm{OH})_{2} \mathrm{Ge}_{2}(\mu-\mathrm{HXylar})_{4} \mathrm{Ge}_{2}(\mu-\right.$ $\left.\mathrm{OH})_{2}\right]^{4-}$ метального комплексу, а також особли- востях розташування ароматичних амінокислот у молекулі ензиму. Слабкі нековалентні зв'язки між молекулами $\alpha$-L-рамнозидази $P$. restrictum і сполуки (7), мабуть, створюють конформацію, яка $€$ найсприятливішою для зближення активних ділянок ензиму із субстратом.

К люч ю в і слов в: Penicillium restrictum IMV F-100139, $\alpha$-галактозидаза, $\alpha$-L-рамнозидаза, ксиларатогерманати різних лігандів та різних металів.

\section{References}

1. Álvarez-Cao ME, Cerdán ME, González-Siso MI, Becerra M. Bioconversion of Beet Molasses to Alpha-Galactosidase and Ethanol. Front Microbiol. 2019; 10: 405.

2. Katrolia P, Rajashekhara E, Yan Q, Jiang Z. Biotechnological potential of microbial a-galactosidases. Crit Rev Biotechnol. 2014; 34(4): 307-317.

3. Rahfeld P, Withers SG. Toward universal donor blood: Enzymatic conversion of $\mathrm{A}$ and $\mathrm{B}$ to $\mathrm{O}$ type. J Biol Chem. 2020; 295(2): 325-334.

4. Li LJ, Liu XQ, Du XP, Wu L, Jiang ZD, Ni H, Li QB, Chen F. Preparation of isoquercitrin by biotransformation of rutin using $\alpha-\mathrm{L}-$ rhamnosidase from Aspergillus niger JMUTS528 and HSCCC purification. Prep Biochem Biotechnol. 2020; 50(1): 1-9.

5. Seifullina II, Martsinko EE, Afanasenko EV. Design and synthesis of newhomo- and heterometal coordination compounds of germanium(IV) for preparationof low toxic drugs with a wide therapeutic action. Odessa Nat Univ Herald Chem. 2015; 20(4): 6-17.

6. Varbanets LD, Nidialkova NA, Borzova NV, Seifullina II, Martsinko EE, Chebanenko EA. Complexes of biscitratogermanates and biscitratostanates with metals are modifiers of Bacillus thuringiensis var. israelensis peptidases and Penicillium canescens, Cladosporium cladosporioides and Aspergillus niger $\alpha$-galactosidases activities. Biotechnologia Acta. 2016; 9(3): 52-60.

7. Tezuka T, Higashino A, Akiba M, Nakamura T. Organogermanium (Ge-132) suppresses activities of stress enzymes responsible for active oxygen species in monkey liver preparation. Adv Enzyme Res. 2017; 5(2): 13-23. 
8. Varbanets LD, Matselyukh EV, Gudzenko EV, Borzova NV, Seifullina II, Khytrych GN. Coordinative compounds of zinc with $\mathrm{N}$-substituted thiocarbamoil-N'pentamethylensulfenamides - activity modifiers of enzymes of proteolytic and glycolytic action. Ukr Biokhim Zhurn. 2011; 83(3): 25-36. (In Russian).

9. Gudzenko OV, Varbanets LD, Seifullina II, Martsinko EE, Pirozhok OV, Chebanenko EA. Germanium coordination compounds for increasing of $\alpha$-L-rhamnosidase activity. Biotechnologia Acta. 2019; 12(4): 19-26.

10. Borzova NV, Gudzenko OV, Varbanets LD, Nakonechnaya LT, Tugay TI. Glycosidase and proteolytic activity of micromycetes isolated from the Chernobyl exclusion zone. Mikrobiol Zh. 2020; 82(2): 51-59. (In Ukrainian).

11. Chaplin ME, Kennedy JE. (Eds.) Carbohydrate analysis: a practical approach. Washington, Oxford: IRL Press, 1986.

12. Davis WB. Determination of Flavanones in Citrus Fruits. Anal Chem. 1947; 19(7): 476-478.

13. Chebanenko EA, Seifullina II, Martsinko EE, Dyakonenko VV, Shishkina SV. Directed structure formation in tetranuclear xylaratogermanates(IV) with complex phenanthrolinecopper(II) cations. Rus J Inorg Chem. 2020; 65(11): 1703-1711.

14. Chebanenko EA, Martsinko EE, Seifullina II, Dyakonenko VV, Shishkina SV. Structural features and properties of heteronuclear germanium(IV) and some $3 \mathrm{~d}$ metal complexes with xylaric acid and 2,2'-bipyridine. J Struct Chem. 2018;59(6):1462-1468.

15. Borzova NV, Varbanets LD. $\alpha$-Galactosidase of Aspergillus niger: purification and properties. Biol Stud. 2007; 1(1): 53-64.

16. Nidialkova NA, Varbanets LD, Chernyshenko VO. Isolation and purification of Bacillus thuringiensis var. israelensis IMV B-7465 peptidase with specificity toward elastin and collagen. Ukr Biochem J. 2016; 88(3): 18-28.

17. Wang QY, Lu J, Liao SM, Du QS, Huang RB. Unconventional interaction forces in protein and protein-ligand systems and their impacts to drug design. Curr Top Med Chem. 2013; 13(10): 11411151.

18. Burghardt TP, Juranić N, Macura S, Ajtai K. Cation-pi interaction in a folded polypeptide. Biopolymers. 2002; 63(4): 261-272.

19. Tu T, Li Y, Su X, Meng K, Ma R, Wang Y, Yao B, Lin Z, Luo H. Probing the role of cation- $\pi$ interaction in the thermotolerance and catalytic performance of endo-polygalacturonases. Sci Rep. 2016; 6: 38413.

20. Gromiha MM, Thomas S, Santhosh C. Role of cation-pi interactions to the stability of thermophilic proteins. Prep Biochem Biotechnol. 2002; 32(4): 355-362. 